DOI: $10.17805 /$ zpu.2015.4.20

\title{
Дифференциация в начальном и среднем образовании России в XVIII веке
}

\author{
А. В. ПЕРЕВОЗНЫЙ
}

(БЕЛОРУССКИЙ ГОСУДАРСТВЕННЫЙ ПЕДАГОГИЧЕСКИЙ УНИВЕРСИТЕТ ИМ. М. ТАНКА)

В статье на основе анализа нормативных документов и историко-педагогической литературы раскрываются основные направления осуществления дифференционных процессов в начальном и среднем образовании России XVIII в. Их результаты проявили себя на трех уровнях: межинституциональном (открытие учебных заведений), внутриинституциональном (структурная организация конкретного учебного заведения), образовательного процесса (набор учебных дисциплин с учетом характера предоставляемой подготовки: общеобразовательной и (или) профессиональной, а также обучение на основе индивидуальных особенностей учащихся). Выделены этапы осуществления дифференционных процессов с учетом их интенсивности и содержательного наполнения.

Дифференционные процессы в первой четверти XVIII в. привели к созданию отдельных учебных заведений, различающихся профессиональной направленностью. К середине века увеличилось число учебных заведения для дворян, в то же время народное образование развивалось крайне медленно.

С 1760-х годов начались многочисленные обсуждения его проблем, завершившиеся созданием разнообразных проектов. Каждый из них мог по-своему запустить дифференционные процессы, которые привели бы к соответствующим результатам в виде определенных типов учебных заведений. В конечном итоге были созданы два типа учебных заведений, каждый из которых имел свое содержание образования и контингент. Они действовали на основе утвержденного устава, преподавание велось по рекомендациям, содержащимся как в общем руководстве, так и по конкретным учебным дисциплинам; для учащихся создавались учебники. Реализованный в 80-х годах XVIII в. проект школьного образования имел ограниченный характер (учебных заведений были лишены сельские жители), однако послужил основой для реформ, проведенных в следующем столетии.

Ключевые слова: процесс дифференциации; история России; история образования России; Россия XVIII века; история педагогики; уровни образования; сословное образование; начальное образование; среднее образование

\section{ВВЕАЕНИЕ}

$\Pi^{1}$ роблемы образования в России XVIII в. многократно становились предметом научного поиска. Среди вопросов, оказавшихся в центре внимания исследователей в последние годы, назовем следующие: государственная политика в области образования во второй половине XVIII в. (Е. П. Титков); развитие педагогических традиций (А. Ю. Бутов, М. В. Савин); зарождение педагогики как науки (А. Х. Газгиреева); становление гражданского образования (О. В. Аебедева); соотношение национального и европейского в педагогической науке и практике (В. А. Петригина); определение влияния реформ второй половины XVIII в. на дальнейшее развитие образования (Е. Ю. Ипатова); характеристика представлений о личностных и профессионально значимых качествах личности, сложившихся в педагогической теории и общественном сознании (Е. Ю. Есенина).

Поскольку рассматриваемый период - это время, когда «речь шла о создании основ системы российского образования» (Богуславский, 2008: 22), постольку потенциальных путей развития было достаточно много, о чем свидетельствуют результаты упомянутых выше исследований. Создание системы школьного образования, призванной обеспечить динамичное развитие страны в эпоху социальных и әкономических трансформаций, сопровождалось многочисленными процессами и течениями, 
имевшими различные цели и направления движения. В настоящей статье становление начального и общего среднего образования рассматривается сквозь призму дифференциации, являющейся одной из сторон процесса развития (Философский энциклопедический словарь, 1989: 177).

\section{НАЧААЬНОЕ И СРЕАНЕЕ ОБРАЗОВАНИЕ В ПЕРВОЙ ПОАОВИНЕ ХVIII ВЕКА}

K началу XVIII в. в России не было государственной системы начального и среднего образования. Существовавшие духовные училища со схоластической моделью преподавания не удовлетворяли потребности государства, начавшего широкомасштабные реформы, в специалистах. В связи с этим появилась необходимость в «организации светской образовательной системы, ориентированной на служение государственным интересам» (Ситаров, 2002: 106), способной за непродолжительное время подготовить кадры к работе в различных сферах. Это обстоятельство привело к возникновению предпосылок для широкого распространения практического направления в образовании.

В первой четверти XVIII в. в России были созданы школы по подготовке артиллеристов, инженеров, врачей, подьячих, а также математических и навигацких наук, гарнизонные, адмиралтейские, горнозаводские, разноязычные. Во все учебные заведения запрещалось принимать детей крепостных; дети солдат, матросов, мастеровых, приказных ограничивались в образовании начальной ступенью школы. Помимо сословности и профессиональной направленности, создаваемые учебные заведения отличались принудительным характером посещения (сбежавших учащихся, достигших 15 лет, подвергали избиению плетьми), жесткой дисциплиной, многопредметностью содержания, доминированием иностранных учителей и учебников.

Новые учебные заведения интегрировали в себе все уровни тогдашнего образования. Показательно в этом отношении положение, существовавшее в школе математических и навигацких наук, открытой в Москве 14 января 1701 г. В ее структуру входили подготовительные классы ( ррусская школа»), где изучались российская грамота и счет; математические классы («цифирная школа»), обеспечивавшие овладение знаниями по арифметике, геометрии, тригонометрии плоской и сферической; старшие классы (навигаторские), где готовили учащихся по навигации, морской астрономии, географии, геодезии, фехтованию. По окончании русской и цифирной школ большинство не дворян поступало на службу, дворянские дети учились в навигаторских классах. В школе была принята классно-предметная группировка учащихся. Это давало возможность переводить их к изучению очередной науки лишь при овладении предыдущей, а из школы выпускать только по мере овладения всеми необходимыми науками (Очерки истории школы ... , 1973: 23-24). В 1715 г. навигаторские классы были переведены в Петербург, и на их базе открылась Морская академия. Школа математических и навигацких наук, просуществовавшая до 1752 г., стала подготовительным звеном для получения образования в академии.

В 1714 г. была предпринята попытка создать начальное образование как самостоятельную ступень. 28 февраля вышел указ императора, согласно которому детей дворян, дьяков и подьячих, а также лиц приказного чина 10-15 лет надлежало учить арифметике и началам геометрии, для чего в губернские города направлялись учащиеся математических школ по нескольку человек. Школы организовывались при архиерейских домах и монастырях (Об обучении дворян ..., 1830: 86). В историю образо- 
вания они вошли под названием цифирных. Однако уже 18 января 1716 г. последовало высочайшее запрещение обучать детей дворян в цифирных школах (О посылке в губернии ..., 1830), и они превратились в элементарные школы для выходцев из семей разного чина, что дало основание считать их всесословными. Однако таковыми они пробыли недолго. В 1726 г. цифирные школы соединились с духовными, в 1731 г. состоялся их перевод в ведение Адмиралтейской коллегии, а в 1744 г. произошло объединение с гарнизонными учебными заведениями. Столь запутанная история свидетельствует о трудностях, которые возникали при создании всеобщих элементарных школ в условиях сословно-профессионального образования. «Преобладание среди учащихся в цифирных школах той или другой сословной группы, - писал С. В. Рождественский, - тянуло эти школы в сторону соединения с соответствующими сословными школами» (Рождественский, 1912: 140).

Господство профессионально-сословного подхода в политике просвещения первой половины XVIII в. обусловило возникновение проблем и у академической гимназии, которая была задумана как первое общеобразовательное среднее учебное заведение в Российской империи для мальчиков из различных свободных сословий. Она была учреждена в 1724 г. вместе с академией и университетом, а первый набор учащихся сделала в 1726 г. Однако существовавшее положение вещей «не позволяло сплотить разнородные социальные элементы среди учащихся в одну учебную массу, подчиненную единому учебному плану и направляемую к единой образовательной цели» (Рождественский, 1912: 173). Общему учебному плану не подчинялись не только дворяне, но и представители других социальных слоев. Они выбирали несколько или даже один предмет, который, как считали, будет необходим в будущем. Аифференциация в таком виде привела к тому, что «гимназия плохо выполняла свое главное назначение - давать университету подготовленных, т. е. прошедших систематический курс среднего образования, учеников» (там же: 171).

Усиление дворянства привело к созданию специальных учебных заведений для выходцев из этого получавшего все больше привилегий сословия. Аля дворянских детей были открыты корпуса, которые вместе с профессиональным предоставляли своим питомцам общее среднее образование. Так, в 1732 г. начал работу первый корпус кадетов, впоследствии переименованный в Сухопутный шляхетный корпус. В 1752 г. создается Морской корпус, в 1759 г. - Пажеский, в 1762 г. - Артиллерийский и Инженерный шляхетные кадетские корпуса.

24 января 1755 г. вышел именной указ императрицы Елизаветы «Об учреждении Московского университета и двух гимназий». В высочайше утвержденном проекте говорилось, что, прежде чем поступать в университет, необходимо «наперед научиться языкам и первым основаниям наук» (Об учреждении Московского университета ... , 1830: 292). Аля этого были учреждены две гимназии: «...одну для дворян, а другую для разночинцев, кроме крепостных людей» (там же). Если крепостной получал вольную и финансовое обеспечение, то он мог претендовать на поступление в гимназию и университет. Было решено учредить в обеих гимназиях по четыре школы, в каждой по три класса. Первая школа - российская, вторая - латинская, третья - первых оснований наук, четвертая - немецкого и французского языков. Аля всех школ было определено свое содержание образования (там же: 292-293). Те учащиеся, которые успешно сдавали публичные экзамены в конце каждого учебного года, переводились в университет, где дворяне и разночинцы обучались совместно. Если родители хотели, чтобы их дети занялись коммерческой или художественной деятельностью, посвяти- 
ли себя военной службе, то об этом рекомендовалось «наперед объявить, дабы по тому учение их расположить было можно» (там же: 293).

Как отмечает С. В. Рождественский, «разделение университетской гимназии на две самостоятельные школы, дворянскую и разночинскую» было «уступкой уже не интересам, а прямо предрассудку дворянства» (Рождественский, 1912: 225). После 1773 г. дворяне и разночинцы занимались по единому учебному плану (там же: 229). Устранение сословного разделения учащихся при сохранении единственного - способностного - свидетельствует о том, что существуют основания дифференциации, которые обусловливаются действующими в обществе стереотипами, разрушение или изменение которых приводит к отмене соответствующего основания.

Аифференциация по способностям и интересам осуществлялась в весьма эффективном варианте. Гимназический курс делился на предметные классы. Так, в 1766 г. в гимназии были такие классы: латинский, французский, немецкий, итальянский, исторический и географический, математический, художеств, письма (там же: 234). Каждый учащийся мог посещать несколько классов одновременно «соответственно своим успехам по разным предметам» (там же: 233). Высшей ступенью гимназического курса был ректорский класс, по окончании которого можно было поступать в университет.

Итак, к середине XVIII в. дифференционные процессы в школьном образовании привели к следующим результатам:

1. Открыт ряд учебных заведений по направлениям профессиональной подготовки, предоставлявших одновременно и общее образование.

2. Образовательные учреждения были разделены не только по профессиональному, но и по сословному признаку.

3. Предпринята попытка создать начальную ступень школьного образования в виде цифирных школ.

4. Учебные заведения получили вертикальную структуру, что позволяло учащимся переходить с одной ступени на другую, каждая из которых имела свое содержание образования.

5. Произошло разделение учебных заведений одного профиля (школа математических и навигацких наук - Морская академия, университетская гимназия - университет) по уровням с одновременным установлением преемственных связей между ними: обучение на предшествующем уровне готовило к обучению на последующем.

6. Содержание образования и организация обучения были ориентированы на учет способностного потенциала учащегося.

XVIII век - время создания разнообразных проектов по организации государственной образовательной системы. Обратимся к одному из них. Его автором является И. И. Шувалов, озаботившийся положением дворянских детей, которые, не имея образования, поступали на службу солдатами, подвергались наказаниям за малейшие нарушения, со временем получали небольшой чин унтер-офицера, к которому не всегда оказывались подготовленными.

Однако получить образование дворянским детям было негде, за исключением немногих учебных заведений, расположенных в столицах. И. И. Шувалов предложил организовать в больших городах гимназии, а в малых - школы грамотности, из которых «молодые люди станут выходить в Гимназии, из Гимназиев в Кадетский Корпус, в Академию, в Университет, а из сих трех мест в действительную службу» (Шувалов, 2010: 256). В результате дворяне могли бы, по мысли И. И. Шувалова, сразу становить- 
ся офицерами, не служа унтер-офицерами или солдатами, не подвергаться наказаниям, неприличным их статусу, и использовать лучшие годы на получение образования (там же: 255$)$.

По поручению Сената И. И. Шувалов обратился к ученым Академии наук с просьбой определить содержание обучения для гимназий и школ. Академики предложили разделить школу и гимназию на состоящие из нескольких классов отделы со своими учебными планами и программами или создать для разных сословий особые школы. Содержание образования в гимназиях предлагалось разнообразным и многопредметным. Граф А. А. Толстой писал: «...в него включались, например, и права естественное и международное и политика, а в так называемых академических гимназиях все вообще юридические науки и даже медицина. Но все академики сходидись в том, что основанием подготовления для высших наук должны служить studia humanitatis» (Толстой, 1883: 19). Они также считали, что школы, которые предполагалось открывать в небольших городах, «следует устроить так, чтобы они, кроме общих начал грамотности для всех необходимых, служили бы и подготовительными училищами для гимназий, или низшими их классами, по нынешнему были бы прогимназиями, из которых ученики переходили бы в гимназии, почему все вводили в их курс латинский язык» (там же).

В связи с кончиной императрицы Елизаветы и отставкой И. И. Шувалова данный план реализован не был. А. А. Толстой считал его «узким, сословным, исключительно дворянским», объясняя это тем, что «в эпоху его составления только одно дворянство, и то в лице лучших своих представителей, было в состоянии ценить образование, и если бы плодами его воспользовалось это сословие, то можно было бы сказать, что оно распространилось на всю страну, разумея под этим именем всех тех, которые сознавали потребность в просвещении» (там же: 17).

\section{РЕФОРМА НАЧАИЬНОГО И СРЕАНЕГО ОБРАЗОВАНИЯ ВО ВТОРОЙ ПОАОВИНЕ ХVIII ВЕКА}

C приходом к власти в 1762 г. Екатерины II политика в области образования начала меняться. В отличие от Петра I она считала воспитание важнее обучения, во главу угла ставила образование общее, а не специальное; больше внимания уделяла народному и женскому образованию.

В марте 1764 г. И. И. Бецкой опубликовал «Генеральное учреждение о воспитании обоего пола юношества...», которое стало идейным фундаментом для создания системы государственного образования в Российской империи. В этом документе утверждалось, в частности: «...прежде нежели отрока обучать какому художеству, ремеслу или науке, надлежит рассмотреть его склонности и охоту и выбор оных оставить ему самому. Аушевные его склонности всемерно долженствуют в том над всеми прочими уважениями преимуществовать, ибо давно доказано, что не преуспевает он ни в чем том, чему будет прилежать по неволе, а не по своему желанию» (Бецкой, 1764: 3).

По инициативе И. И. Бецкого, который действовах по поручению Екатерины II, стали открываться учебные заведения различных типов. Среди них Смольный институт (1764 г.), Мещанское училище (1765 г.), воспитательные дома в Москве (1764 г.) и Петербурге (1770 г.). Все они были предназначены для реализации идеи по воспитанию «новой породы» людей, которой увлеклась Екатерина II в начальный период своего царствования. 
Смольный институт благородных девиц был первым государственным средним учебно-воспитательным учреждением для женщин. Он имел 12-летний курс обучения; воспитанницы делились на четыре возраста: от 6 до 9 лет, от 9 до 12, от 12 до 15, от 15 до 18 лет. Аля каждого возрастного этапа предназначались свои учебные дисциплины (Анепров, Усачева, 2009: Электронный ресурс). В самом начале это были только дворянки, но уже 31 января 1765 г. появилось отделение для девочек из семей чиновников, купцов и мещан. Содержание образования на «мещанском» и «благородном» отделениях значительно различалось (там же). Оно определялось сословным предназначением обучавшихся. Таким образом, «женское среднее образование, несмотря на свой “бессословный” замысел, пошло тем же путем, что и мужское, - путем сословным» (там же).

В «Уставе воспитания двухсот благородных девиц...» говорится, в частности, следующее: «Излишними понятиями незрелый еще разум их отягощать не должно, поелику не все могут быть равного сложения, ибо найдутся и скоропонятные и медлительные в понятии»; «сколь скоро усмотрится, что природная способность к обучению воспрепятствована собственным нехотением или упрямством, надлежит тотчас употреблять пристойные способы к отвращению онаго»; «праздность почитается источником всех пороков; того ради госпожи учительницы должны прилежно наблюдать прямые в обучении успехи каждой девицы, також прилежание и леность, что наипаче во время приватных в классах экзаменов усмотреть можно, дабы по тому располагать должные к тому способы для возбуждения в них вящей к обучению ревности похвалою их успехов, или каким-нибудь и награждением» (Устав воспитания ... , 1774: 53).

Немногочисленные учебно-воспитательные учреждения, открытые на территории Российской империи, не снимали проблемы народного образования. Между тем государство считало необходимым этот вопрос каким-то образом решать.

Так, в 1764 г. был составлен «Генеральный план гимназий или государственных училищ». В нем отмечалось, что «...для избежания беспорядочного учения, которому свойственно воспоследовать, ежели обучать в одном училище детей, назначенных к разному званию и роду жития, представляются здесь четыре рода училищ, разными наименованиями различенных, а именно: училища для ученых людей, военные, гражданские и купеческие. Эти четыре рода школ будут разделены по губерниям по воле Ея Императорского Величества и смотря на то, где каких жителей больше» (Материалы ..., 1910: 104-105). В первой главе плана утверждалось: «...все рожденные российские подданные греческого исповедания (исключая крепостных) могут иметь участие без всякого различия знания и природы во всевысочайшей сей Императорской милости и в надежде быть приняты в сии училища, ежели они только имеют потребные качества <..> и ежели только родители на предписанные им условия согласятся. Между всеми же преимущественно будут пользоваться сею милостию бедные всякого звания, которым родители не в состоянии дать доброго воспитания сами и принесут о том надлежащую просьбу» (там же: 103-104). Содержание образования определялось направленностью училища.

Училища предполагалось разделить на три класса, в каждом классе планировалось четырехлетнее обучение. Таким образом, будучи принятыми в училище в 5-6-летнем возрасте, учащиеся покидали бы его в 18 лет. Екатерина II не утвердила этот план.

В 1768 г. была сформирована «Частная комиссия об училищах и призрения требующих». Она предложила создать учебные заведения четырех типов: нижние де- 
ревенские училища, нижние городские училища, средние училища, училища для иноверцев.

Комиссия сочла необходимым ввести обязательное обучение мальчиков от 8 до 12 лет чтению и открыть с этой целью школы в каждом селе и в крупных деревнях. Аевочки также могли учиться, но по желанию родителей. Обучение письму могло быть организовано за плату (там же: 225-226). Нижние городские училища предназначались для обязательного обучения мальчиков - выходцев из мещанских семей от 7 лет и старше чтению и письму, девочек - чтению, а по желанию родителей также и письму (там же: 236). Строить и содержать школы должны были горожане. $\mathrm{K}$ разряду средних училищ причислялись гимназии. Они предназначались для детей дворян и разночинцев, но дворяне отделялись от детей других сословий как в быту, так и в процессе обучения (там же: 253). Гимназии Комиссия предполагала разместить в монастырях; руководство гимназиями отдавалось светским и церковным властям (там же: 246). Аля оседлых иноверцев также запланировали создать специальные училища, не вменяя им в обязанность обязательность посещения. Предполагалось, что учителями инородцев станут их единоверцы (там же: 241). План остался нереализованным.

Попытка практической организации системы народного просвещения была предпринята в 1775 г., когда в каждой губернии были созданы Приказы общественного призрения, которым было вменено в обязанность открывать народные школы в городах и больших селах (Благочестивейшой ..., 1775: 154). В отличие от петровского периода, когда в цифирные школы учащихся зачисляли принудительно, во вновь открываемых учебных заведениях обучение предполагалось вести на добровольной основе, причем неимущие могли посещать школу «без платежа», «а имущие за умеренную плату» (там же: 157). В народных школах рекомендовалось обучать грамоте, рисованию, письму, арифметике, православных — катехизису (там же: 157).

На основе сохранившихся данных А. С. Воронов сделал заключение о том, что «приказы в первое время действовали весьма медленно при заведении училищ. Не имея ни учителей, ни руководств и не зная, как приняться за дело, они, естественно, и не могли успеть в нем; школы открывались только кое-где и кое-какие» (Воронов, 1858: 88). Ссылаясь на официальные документы, он упоминает о школах, открытых в Олонце, Петрозаводске, Калуге, Туле, Ярославле, Вологде, Москве, Новой Мадоге, Рязани, Санкт-Петербурге (там же).

Екатерина II, «не удовлетворившись полумерами, имевшими притом местное и ограниченное влияние», решилась на распространение образования по всей империи «на прочных непоколебимых началах» (там же: 89). Из имевшихся альтернативных проектов «императрица выбрала самую лучшую, по ее мнению, в Европе австрийскую систему образования и захотела внедрить ее “сверху” в народную жизнь» (Степашко, 1999: 128).

В 1782 г. была сформирована Комиссия об учреждении училищ. 5 августа 1786 г. императрица утвердила подготовленный Комиссией «Устав народным училищам в Российской империи». С этого времени, как отмечает С. В. Рождественский, «кончается эпоха заимствования отвлеченных идей и начинается эпоха заимствования учреждений» (Рождественский, 1912: 329). При этом на российскую почву был перенесен основной принцип австрийского школьного образования - его полное единообразие как в организационных основах школы, так и «в книгах и учебном способе, чтоб не воспоследовало ни в учителях, ни в книгах какого разврата ко вреду общей 
пользы» (там же: 611). Таким образом, дифференционные процессы при создании новых учебных заведений на территории Российской империи были существенно ограничены.

В соответствии с уставом в губернских городах открывались главные училища, в уездных, а также и губернских городах, если одного главного не хватало, - малые. 22 сентября 1786 г. начали работу 25 главных народных училищ. Создававшаяся сеть учебных заведений была рассчитана на жителей губернских и уездных городов. В сельской местности создание учебных заведений не предполагалось.

Главные училища состояли из четырех разрядов, или классов с пятилетним сроком обучения. Учащимся главных народных училищ предлагалась широкая общеобразовательная подготовка. Она значительно расширялась на четвертом году обучения. Помимо Закона Божия, чтения, письма, арифметики, в школах преподавались русская и всеобщая история и география, русская грамматика, основы геометрии, механики, физики, естественной истории и гражданской архитектуры, рисование. Аля желающих поступать в гимназии и университеты с первого класса предлагалось изучать латынь, а также язык той страны, которая граничит с территорией, на которой находится училище (Высочайше утвержденный Устав народным ... , 1830: 646-648). В малых училищах преподавались те же предметы, что и в первых двух классах главных (кроме иностранных языков).

Итак, впервые в истории России была открыта государственная общеобразовательная школа, бессословная и бесплатная, пришедшая на смену школе сословной и профессиональной. Училища работали по единым учебным планам, следовали единым принципам обучения и нормам поведения учителей и учащихся.

Привлечению в школы детей бедных родителей уделялось особое внимание. Так, в главе «О должностях учительских» Устава говорилось: «Они должны всех в классы их приходящих учеников и учениц обучать, не требуя от них никакой платы за учение. При самом же обучении не должны они пренебрегать детей бедных родителей, но всегда иметь в памяти, что они приуготовляют члена обществу» (там же: 649). Кроме того, учителям рекомендовалось «стараться всеми силами, дабы ученики преподаваемые им предметы ясно и правильно понимали» (там же: 649).

К открытию училищ было подготовлено «Руководство учителям первого и второго класса народных училищ Российской империи...». В нем говорилось о том, что учитель должен «по различию учеников и поступки свои различно устроять» (Руководство ..., 1789: 88). Ученики различались по состоянию, полу, способностям, памяти и мышлению, нраву, поведению. В соответствии с этими особенностями учителю предлагались тактики обучения (там же: 88-94). В самом общем виде модель дифференцированного обучения школьников выглядела следующим образом. Необходимо «разделять и тех, которые одному чему обучаются, но с различным успехом, и сажать особливо хороших, особливо посредственных и особливо слабых» (там же: 3). Учителю предлагалось «особливо пособлять» «слабым ученикам и заставлять их чаще отвечать и повторять ответы других. Но дабы сии его долго не задерживали, то может он продолжать далее, если по малой мере две трети учеников предыдущее совсем поняли. Те же немногие, которые во всю школьную пору за прочими следовать не успевали, должны или ходить еще один раз в тот класс, в котором они отставали, или учитель должен им сверх обыкновенных часов показывать особливо» (там же: 4).

В народных училищах, созданных по Уставу 1786 г., социальный состав учащихся был неоднородным. Так, в московских училищах конца XVIII в. дети дворовых со- 
ставляли более 50\%. Это объясняется увеличением в Москве дворянского населения, которое нуждалось в грамотной прислуге. Второе место занимали купцы, мещане, приказные. Аетей дворян было немного, так как они обучались в университетских гимназиях и в благородном пансионе (Мепская, 1973: 94-95).

Итак, к концу правления Екатерины II дифференционные процессы в школьном образовании привели к следующим результатам:

1. В городах работали малые и большие училища, в которых можно было получить начальное и среднее образование.

2. В основу школьного образования были положены интересы детей, больше внимания уделяли их воспитанию, духовному развитию, что подчас лишало содержание образования прикладной направленности. Издававшиеся уставы и руководства для школ «старались вдохнуть совершенно новый дух, указать на главную цель воспитания - гуманное развитие воспитанников» (Аемков, 1917: 46); в них находил отражение новый взгляд на человека как «меру всех вещей», который «вызвал к жизни тенденцию учета индивидуальных особенностей и возрастных возможностей ребенка» (Гончаров, 2011: 127).

3. Вертикальная структура школы приобрела расчлененность благодаря внедрению классно-урочной системы. Учащихся стали переводить из класса в класс не по возрасту, а на основе достигнутых результатов.

4. Произошло разделение общего и профессионального образования.

5. В содержание общего образования были включены разнообразные дисциплины, что способствовало гармоничному развитию учащихся.

На основе изложенного можно сделать вывод, что дифференционные процессы на протяжении XVIII в. имели несколько этапов, выделяемых с учетом их интенсивности и содержательного наполнения.

Первый этап (1701-1725 гг.). Аля модернизации всех сторон жизни общества, проводившейся в это время, требовались специалисты-практики. В связи с этим дифференциация в образовании проводилась по профессиональному признаку. Она осуществлялась достаточно интенсивно; учебные заведения открывались по всей стране в зависимости от места нахождения соответствующего производства.

Второй этап (1725-1761 гг.). Сеть образовательных учреждений продолжала развиваться за счет открытия учебных заведений для дворян. В то же время образованию детей из народа внимание не уделялось; открытые для них на предыдущем этапе учебные заведения или приходили в упадок, или трансформировались, а новые не создавались.

Третий этап (1762-1782 гг.). Изучались идеи зарубежной педагогической мысли; создавались учебные заведения закрытого типа для детей дворян, бедняков, сирот. Состоялось открытие народных школ Приказами общественного призрения.

Четвертый этап (1782-1786 гг.). Подготовлена и проведена школьная реформа, в результате которой в городах были открыты начальные и средние общеобразовательные учебные заведения, предназначенные для детей всех сословий, за исключением крепостных. Уточнено содержание образования, обоснована необходимость проведения дифференцированного обучения учащихся. Пути его осуществления раскрывались в руководствах, в методических указаниях по изучению конкретных учебных дисциплин. 


\section{ЗАКАЮЧЕНИЕ}

XVIII век - время достаточно интенсивных институциональных процессов в начальном и среднем образовании России. В этот период проявили себя две тенденции в определении роли образования как социального института. Первая из них была обусловлена необходимостью кадрового обеспечения растущего промышленного производства, вторая - заботой о духовном состоянии общества.

В начале XVIII в. доминировала первая тенденция, поскольку Петру I для воплощения задуманных реформ нужны были специалисты, владеющие практически полезными знаниями, и поэтому открывались школы, готовящие моряков, инженеров, техников, архитекторов. В то же время сами учебные заведения носили ярко выраженный интегративный характер: они предоставляли своим питомцам одновременно и начальное, и среднее, и профессиональное образование. Такой формат являлся мерой вынужденной, поскольку создававшиеся учебные заведения были единственными в своем роде, а система начального и среднего образования в стране отсутствовала.

Екатерина II в большей степени «склонялась к просвещению общечеловеческому» (Аемков, 1917: 32). Отсюда - усиление общего образования, которое является фундаментом, на котором только и «может уже воздвигнуться здание специализации в той или другой практической области» (Очерки истории народного образования ... , 1910: 63). Переход преимущественной роли к общеобразовательной школе, «которая с тех пор навсегда сохраняет свое главенствующее положение», не означал отказа от образования профессионального. Профессиональная школа продолжала существовать, «насколько она нужна была для удовлетворения практических нужд государства», «служа целям специализации» (там же).

На протяжении всего XVIII в. источниками дифференционных процессов, приводивших к существенным изменениям в сфере образования Российской империи, были царствующие особы. Они инициировали процессы, подбирали ответственных исполнителей, которые подводили под проводимые реформы обоснование, вырабатывали пути их осуществления, а затем одобряли или отвергали предложенные подходы. Общество в силу своей консервативности слабо влияло на образовательную политику властей. Отсюда большое значение приобретали личные воззрения монарха, его предрасположенность ставить и решать проблемы народного просвещения. Условия развития страны были такими, что потребность в образованных людях постоянно возрастала. Монархи в силу собственного понимания встающих перед страной задач не могли не реагировать на это, пытались создать необходимую базу для развития промышленности, армии и флота.

Теоретико-методологическое значение образовательной практики XVIII в. заключается в том, что на его протяжении произошел поворот от профессиональной к личностно-ориентированной модели обучения и воспитания. Именно тогда началось содержательное наполнение понятий «дифференцированное обучение», «элективные курсы» без их терминологического обозначения. Что же касается понятия «образовательный профиль», то оно практически начало формироваться еще при открытии профессиональных учебных заведений в Петровскую эпоху, содержание обучения в которых соответствовало направлению предоставляемой ими подготовки.

\section{СПИСОК АИТЕРАТУРЫ}

Бецкой, И. И. (1764) Генеральное учреждение о воспитании обоего пола юношества. СПб. : Сенатская типография. 4 с. 
Благочестивейшой самодержавнейшой Великой Государыни Императрицы Екатерины Второй учреждения для управления губерний Всероссийской империи. (1775) М. : Сенатская типография. 236 с.

Богуславский, М. В. (2008) Системный характер реформ российского образования XVIII-XX веков // Очерки системной педагогики : сб. науч. трудов / под ред. Р. А. Аачашвили. М. : Сентябрь. 384 с. С. 20-42.

Воронов, А. С. (1858) Федор Иванович Янкович де Мириево, или Народные училища в России при императрице Екатерине II-й. СПб. : Тип. Э. Праца. 168 с.

Высочайше утвержденный Устав народным училищам в Российской империи, 5 августа 1786 г. (1830) // Полное собрание законов Российской империи : [Собрание первое : С 1649 г. по 12 декабря 1825 года] : [в 45 т.] СПб. : Тип. II Отделения собственной Е. И. В. канцелярии. Т. XXII: $1784-1788.1175$ с. С. $646-662$.

Гончаров, М. А. (2011) Основные тенденции образования и воспитания в России XVIII в. М. : Интеллект-Центр. 142, [1] с.

Аемков, М. И. (1917) Очерки по истории русской педагогики. 4-е изд., испр. М. : Тип. Т-ва И. А. Сытина. VI, [2], 144 с.

Анепров, Э. А., Усачева, Р. Ф. (2009) Среднее женское образование в России : учеб. пособие. M. [Электронный ресурс] // Высшая школа экономики. URL: http://hse.ru/pubs/share/direct/ document/80283818 [архивировано в WebCite] (дата обращения: 7.04.2015).

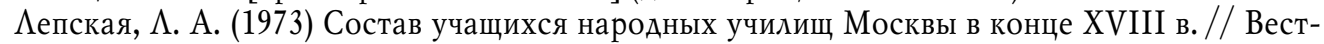
ник Московского университета. Серия 8. История. № 5. С. 88-96.

Материалы для истории учебных реформ в России в XVIII-XIX веках (1910) / сост. С. В. Рождественский при участии В. Г. Соломина и П. П. Тодорского. СПб. : Тип. Т-ва «Общественная польза». [2], 397 с.

О посылке в губернии по два учителя для обучения детей арифметике и геометрии : Указ (Именной, объявленный из Сената 18 января 1716 г.) императора Петра I (1830) // Полное собрание законов Российской империи : [Собрание первое : С 1649 г. по 12 декабря 1825 года] : [в 45 т.] СПб. : Тип. ІІ Отделения собственной Е. И. В. канцелярии. Т. V: 1713-1719. 784 с. C. 189.

Об обучении дворян приказного чина, дьячьих и подьяческих детей арифметике и геометрии, о посылке для того в губернии учеников из математических школ и об учреждении училищ при архиерейских домах и монастырях : Указ (Именной, объявленный из Сената 28 февраля 1714 г.) императора Петра I (1830) // Полное собрание законов Российской империи : [Собрание первое : С 1649 г. по 12 декабря 1825 года] : [в 45 т.] СПб. : Тип. II Отделения собственной Е. И. В. канцелярии. Т. V: 1713-1719. 784 с. С. 86.

Об учреждении Московского университета и двух гимназий : Указ (Именной) императрицы Елизаветы, 24 января 1755 г. (1830) // Полное собрание законов Российской империи : [Собрание первое : С 1649 г. по 12 декабря 1825 года] : [в 45 т.] СПб. : Тип. IІ Отделения собственной Е. И. В. канцелярии. Т. XIV: 1754-1757. 994 с. С. 284-294.

Очерки истории народного образования в России до эпохи реформ Александра II (1910) / сост. С. А. Князьков, Н. И. Сербов ; под ред. С. В. Рождественского. М. : Польза, В. Антик и Кํ. $240 \mathrm{c}$.

Очерки истории школы и педагогической мысли народов СССР : XVIII в. - первая половина XIX в. (1973) / отв. ред. М. Ф. Шабаева. М. : Педагогика. 608 с.

Рождественский, С. В. (1912) Очерки по истории систем народного просвещения в России в XVIII-XIX веках. СПб. : Тип. М. А. Александрова. 738 с.

Руководство учителям первого и второго класса народных училищ Российской империи, изданное по Высочайшему повелению царствующей императрицы Екатерины Второй. (1789) СПб. : Тип. Брейткопфа. 114 с.

Ситаров, В. А. (2002) Аидактика / под ред. В. А. Сластенина. М. : Изд. центр «Академия». 368 с.

Степашко, $\Lambda$. А. (1999) Философия и история образования. М. : Моск. психолого-социальный ин-т ; Флинта. 272 с. 
Толстой, А. А. (1883) Взгляд на учебную часть в России в XVIII столетии до 1782 года. СПб. : Тип. Имп. Акад. наук. [2], 100 с.

Устав воспитания двухсот благородных девиц (1774) // Учреждения и уставы, касающиеся до воспитания и обучения в России юношества обоего пола : в 2 т. СПб. : б/и. Т. 2. 244 с. C. 37-68.

Философский энциклопедический словарь (1989) / редколл.: С. С. Аверинцев, Э. А. АрабОглы, $\Lambda$. Ф. Ильичев и др. 2-е изд. М. : Сов. энциклопедия. 815 с.

Шувалов, И. И. (2010) В Правительствующий Сенат Императорского Московского университета от куратора Шувалова доношение (1 ноября 1760 г.) // Шувалов П. И., Шувалов И. И. Избранные труды / [сост., коммент. С. В. Андриайнена, авторы вступ. ст. С. В. Андриайнен, А. Б. Каменский]. М. : Российская политическая энциклопедия (РОССПЭН). 344 с. С. 252-257.

Аата поступления: 29.04.2015 2.

\section{DIFFERENTIATION IN RUSSIAN PRIMARY AND SECONDARY EDUCATION IN THE $18 T H$ CENTURY}

\section{A. V. PEREVOZNY}

(Maxim Tank Belarusian State Pedagogical University)

By analyzing both regulatory documents and historical and pedagogical literature, the article examines the basic directions of implementing differentiation in primary and secondary education in Russia during the 18th century. The outcomes of differentiation appear at three levels: inter-institutional (the establishment of educational institutions), intra-institutional (the structural organization of each particular institution), and that of the educational process (a set of academic disciplines with regard to the nature of training provided: general education and/or vocational education, as well as individual tuition). We also outline a number of stages in implementing differentiation with regard to its intensity and substance.

In the first quarter of the 18th century, differentiation led to the establishment of a number of schools with various professional orientations. By the middle of the century, schools for the nobility proliferated, whereas the narodnye uchilishcha (state-supported schools for the general public) were developing very slowly.

Since the 1760s, numerous discussions were devoted to the problems of public education, giving rise to a number of projects. Each of them could have set off differentiation in its own way, which would lead to establishing specific types of educational institutions. In the end, two types of schools were created, each with its own educational content and audience. They acted on the basis of the officially approved statute, teaching had to follow the recommendations both of the general manual and discipline-based guidebooks; textbooks for students were also written. The school education project implemented in the 1780s had a limited character (rural residents were still deprived of schooling), but it lay the cornerstone for the reforms of the century to follow.

Keywords: differentiation process; Russian history; history of Russian education; Russia in the 18th century; history of pedagogy; education levels; estate-based education; primary education; secondary education

\section{REFERENCES}

Betskoi, I. I. (1764) General' noe uchrezbdenie o vospitanii oboego pola iunoshestva [The general establishment of education of youth of both sexes]. St. Petersburg, Senatskaia tipogafiia [Senate Printing House]. 4 p. (In Russ.).

Blagochestiveishoi samoderzhavneishoi Velikoi Gosudaryni Imperatritsy Ekateriny Vtoroi uchrezhdeniia dlia upravleniia gubernii Vserossiiskoi imperii [Most pious and powerful Great Empress Catherine II's institutions for managing the provinces of the Russian empire]. (1775) Moscow, Senatskaia tipografiia [Senate Printing House]. 236 p. (In Russ.).

Boguslavskii, M. V. (2008) Sistemnyi kharakter reform rossiiskogo obrazovaniia XVIII-XX vekov [The systemic nature of educational reforms in Russia in the 18th-20th centuries]. In: Ocberki si- 
stemnoi pedagogiki [Essays on systemic pedagogy] : collection of articles / ed. by R. A. Lachashvili. Moscow, Sentiabr' Publ. 384 p. Pp. 20-42. (In Russ.).

Voronov, A. S. (1858) Fedor Ivanovich Iankovich de Mirievo, ili Narodnye uchilishcha v Rossii pri imperatritse Ekaterine II-i [Fedor Ivanovich Iankovich de Mirievo, or schools for the general public in Russia under Empress Catherine II]. St. Petersburg, Tipografiia E. Pratsa [E. Prats's Printing House]. 168 p. (In Russ.).

Vysochaishe utverzhdennyi Ustav narodnym uchilishcham v Rossiiskoi imperii, 5 avgusta 1786 g. [Statute of schools for the general public in the Russian Empire, approved by Her Majesty on August 5 , 1786]. (1830) In: Polnoe sobranie zakonov Rossiiskoi imperii : Sobranie pervoe : S $1649 \mathrm{~g}$. po 12 dekabria $1825 \mathrm{~g}$. [The complete collection of laws of the Russian empire: 1649 to December 12, 1825]: in 45 vols. St. Petersburg, Tipografiia II Otdeleniia sobstvennoi E. I. V. kantseliarii [Printing House of the Second Department of His Imperial Majesty's Office]. Vol. XXII: 1784-1788. 1175 p. Pp. 646-662. (In Russ.).

Goncharov, M. A. (2011) Osnovnye tendentsii obrazovaniia $i$ vospitaniia $v$ Rossii XVIII $v$. [The main trends of education and development in Russia in the 18th century]. Moscow, Intellekt-Tsentr Publ. 142, [1] p. (In Russ.).

Demkov, M. I. (1917) Ocherki po istorii russkoi pedagogiki [Essays on the history of Russian pedagogy]. 4th edn. Moscow, Tipografiia T-va I. D. Sytina [Printing House of I. D. Sytin's Co]. VI, [2], 144 p. (In Russ.).

Dneprov, E. D. and Usacheva, R. F. (2009) Srednee zhenskoe obrazovanie v Rossii [Secondary education for women in Russia] : A textbook. Moscow / Vysshaia shkola ekonomiki [online] Available at: http://hse.ru/pubs/share/direct/document/80283818 [archived in WebCite] (accessed 7.04.2015). (In Russ.).

Lepskaia, L. A. (1973) Sostav uchashchikhsia narodnykh uchilishch Moskvy v kontse XVIII v. [Students at Moscow schools for the general public at the end of the 18th century]. Vestnik Moskovskogo universiteta. Seriia 8. Istoriia, no. 5, pp. 88-96. (In Russ.).

Materialy dlia istorii uchebnykb reform $v$ Rossii $v$ XVIII-XIX vekakb [Materials for the history of education reforms in Russia in the 18th-19th centuries]. (1910)/ comp. by S. V. Rozhdestvenskii, V. G. Solomin and P. P. Todorskii. St. Petersburg, Tipografiia T-va «Obshchestvennaia pol'za» [Printing House of Obshchestvennaia pol'za Co]. [2], XVI, 397 p. (In Russ.).

O posylke v gubernii po dva uchitelia dlia obucheniia detei arifmetike i geometrii : Ukaz (Imennoi, ob'iavlennyi iz Senata 18 ianvaria 1716 g.) imperatora Petra I [A personal decree of Emperor Peter I declared in Senate on January 18,1716 , on sending two teachers to every gubernia to teach arithmetic and geometry to children]. (1830) In: Polnoe sobranie zakonov Rossiiskoi imperii : Sobranie pervoe : $S 1649$ g. po 12 dekabria 1825 goda [The complete collection of laws of the Russian Empire : First collection : 1649 to December 12, 1825] : in 45 vols. St. Petersburg, Tipografiia II Otdeleniia sobstvennoi E. I. V. kantseliarii [Printing House of the Second Department of His Imperial Majesty's Office]. Vol. V: 1713-1719. 784 p. P. 189. (In Russ.).

Ob obuchenii dvorian prikaznogo china, d'iach'ikh i pod'iacheskikh detei arifmetike i geometrii, o posylke dlia togo v gubernii uchenikov iz matematicheskikh shkol i ob uchrezhdenii uchilishch pri arkhiereiskikh domakh i monastyriakh : Ukaz (Imennoi, ob»iavlennyi iz Senata 28 fevralia 1714 g.) imperatora Petra I [A personal decree of Emperor Peter I declared in Senate on February 28, 1714, on training junior nobility, children of diaks and podyachii in arithmetic and geometry, on sending students at mathematical schools to the gubernias and in establishing schools at bishops' courts and in monasteries]. (1830) In: Polnoe sobranie zakonov Rossiiskoi imperii : Sobranie pervoe : $S 1649 \mathrm{~g}$. po 12 dekabria 1825 goda [The complete collection of laws of the Russian empire : First collection : 1649 to December 12, 1825] : in 45 vols. St. Petersburg, Tipografiia II Otdeleniia sobstvennoi E. I. V. kantseliarii [Printing House of the Second Department of His Imperial Majesty's Office]. Vol. V: 1713-1719. 784 p. P. 86. (In Russ.).

Ob uchrezhdenii Moskovskogo universiteta i dvukh gimnazii : Ukaz (Imennoi) imperatritsy Elizavety, 24 ianvaria $1755 \mathrm{~g}$. [A personal decree of Empress Elizabeth on establishing a university and two gymnasia in Moscow, January 24, 1755]. (1830) In: Polnoe sobranie zakonov Rossiiskoi imperii : 
Sobranie pervoe : S $1649 \mathrm{~g}$. po 12 dekabria $1825 \mathrm{~g}$. [The complete collection of laws of the Russian empire : First collection : 1649 to December 12, 1825] : in 45 vols. St. Petersburg, Tipografiia II Otdeleniia sobstvennoi E. I. V. kantseliarii [Printing House of the Second Department of His Impe-rial Majesty's Office]. Vol. XIV: 1754-1757. 994 p. Pp. 284-294. (In Russ.).

Ocherki istorii narodnogo obrazovaniia $v$ Rossii do epokbi reform Aleksandra II [Essays on the history of public education in Russia before the reforms of Alexander II] (1910) / comp. by S. A. Kniazkov and N. I. Serbov ; ed. by S. V. Rozhdestvenskii. Moscow, Pol'za Publ., V. Antik i K ${ }^{\circ}$ IV, 240 p. (In Russ.).

Ocherki istorii shkoly $i$ pedagogicheskoi mysli narodov SSSR: XVIII v. - pervaia polovina $X I X v$. [Essays on the history of school and pedagogical thought of peoples of the USSR: The 18th first half of the 19th century] (1973) / ed. by M. F. Shabaeva. Moscow, Pedagogika Publ. 608 p. (In Russ.).

Rozhdestvenskii, S. V. (1912) Ocherki po istorii sistem narodnogo prosveshcheniia $v$ Rossii $v$ XVIII-XIX vekakb [Essays on the history of public education systems in Russia in the 18th-19th centuries]. St. Petersburg, Tipografiia M. A. Aleksandrova [M. A. Aleksandrov's Printing House]. 738 p. (In Russ.).

Rukovodstvo uchiteliam pervogo $i$ vtorogo klassa narodnykb uchilishch Rossiiskoi imperii, izdannoe po Vysochaishemu poveleniiu tsarstvuiushchei imperatritsy Ekateriny Vtoroi [A manual for 1st and 2nd grade instructors at schools for the general public of the Russian Empire, printed by the highest appointment of the reigning Empress Catherine II]. (1789) St. Petersburg, Tipografiia Breitkopfa [Breitkopf's Printing House]. 114 p. (In Russ.).

Sitarov, V. A. (2002) Didaktika [Didactics]. Moscow, Akademia Publ. 368 p. (In Russ.).

Stepashko, L. A. (1999) Filosofiia $i$ istoriia obrazovaniia [The philosophy and history of education]. Moscow, Moscow Psychological and Social Institute Publ. ; Flinta Publ. 272 p. (In Russ.).

Tolstoy, D. A. (1883) Vzgliad na uchebnuiu chast' $v$ Rossii $v$ XVIII stoletii do 1782 goda [A survey of teaching in Russia in the 18th century prior to 1782]. St. Petersburg, Tipografiia Imperatorskoi Akademii nauk [Printing House of the Imperial Academy of Sciences]. [2], 100 p. (In Russ.).

Ustav vospitaniia dvukhsot blagorodnykh devits [Statute of an establishment for two hundred noble ladies]. (1774) In: Uchrezhdeniia i ustavy, kasaiushchiesia do vospitaniia $i$ obucheniia v Rossii iunoshestva oboego pola [Establishments and statutes relating to education and training youth of both sexes in the Russia] : in 2 vols. St. Petersburg, s/n. Vol. 2. 244 p. Pp. 37-68. (In Russ.).

Filosofskii entsiklopedicheskii slovar' [An encyclopedic dictionary of philosophy] (1989)/ ed. by S. S. Averintsev, E. A. Arab-Ogly, L. F. Ilichev et al. 2nd edn. Moscow, Sovetskaia Entsiklopediia Publ. 815 p. (In Russ.).

Shuvalov, I. I. (2010) V Pravitel'stvuiushchii Senat Imperatorskogo Moskovskogo universiteta ot kuratora Shuvalova donoshenie (1 noiabria 1760 g.) [To the Governing Senate of Imperial Moscow University, a memorandum by Curator Shuvalov (November 1, 1760)]. In: Shuvalov, P. I. and Shuvalov, I. I. Izbrannye trudy [Selected works] / [comp., comment. by S. V. Andriainen, introduct. by S. V. Andriaine and A. B. Kamenskii]. Moscow, Rossiiskaia politicheskaia entsiklopediia (ROSSPEN) Publ. 344 p. Pp. 252-257. (In Russ.).

Submission date: 29.04.2015.

Перевозный Алексей Владиславович - кандидат педагогических наук, доцент кафедры педагогики Белорусского государственного педагогического университета им. Максима Танка. Адрес: 220050, Республика Беларусь, г. Минск, ул. Советская, А. 18. Тел.: +3 (7517) 327-77-59. Эл. aspec: palexei1@rambler.ru

Perevozny Alexei Vladislavovich, Candidate of Pedagogy, Associate Professor, Department of Pedagogy, Maxim Tank Belarusian State Pedagogical University. Postal address: 18 Sovetskaya St., 220050 Minsk, Republic of Belarus. Tel.: +3 (7517) 327-77-59. E-mail: palexei1@rambler.ru 